\title{
Terapia ocupacional en psiquiatría y salud mental: formación en pregrado
}

\author{
Laura Rueda y Paula Soto
}

\section{- Resumen}

La gran responsabilidad que nos depara tener a cargo la formación de los Terapeutas Ocupacionales en el área de Psiquiatría y Salud Mental a nivel de pregrado nos compromete por una parte, a una constante actualización de contenidos clínicos y procedimientos de intervención que las demandas sanitarias van determinando; por otro lado de igual forma tenemos la necesidad de ir adoptando metodologías mas efectivas del proceso enseñanza-aprendizaje de los elementos del área El trabajo que aquí presentamos constituye una evaluación parcial de la metodología que en el presente año académico se esta desarrollando en la asignatura de: Modelos de intervención de Terapia Ocupacional en Psiquiatría y Salud Mental, enmarcada en los fundamentos que originan el trabajo en una de las especialidades tradicionales de la disciplina y en la nueva visión de indusion social de la enfermedad y la discapacidad de causa psíquica.

\begin{abstract}
- Abstract
The great responsability that affortds us to be responsible for the formation of the Occupational Therapists in the area of Psychiatry and Mental Health at pregrado levell it commits us on one hand, to a constant upgrade of clinical contents and intervention procedures that the sanitary demands go dtermining; on the otherr hand of equal it forms we have the necessity to go adopting more effective methodologies of the process teaching-learning of lhe etements of the area. The work that here present it constitutes a partial evaluation of the methodology that presently academic year it is developing in the subject of: Models of Intervention of Occupational Therapy in Psychiatry and Mental Health, framed in the foundations that originate the work in one of the traditional specialties of the discipline and in the new vision of social inclusion of the illness and the handicapped of psychic cause.
\end{abstract}

\footnotetext{
Universidad de Chile Facultad de Medicina Escuela de Terapia Ocupacional. Contacto > > Universidad de Chile Facultad de Medicina Escuela de Terapia Ocupacional Av. Independencia 1027. Santiago de Chile Irueda@machi.med.uchile.cl psoto@machi.med.uchile.cl
} 